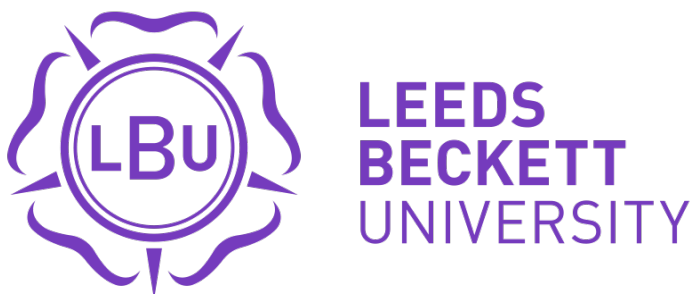

Citation:

Verhoeven, P and Tench, R and Zerfass, A and Moreno, A and Verčič, D (2014) Crisis? What crisis?. How European professionals handle crises and crisis communication. Public Relations Review, 40 (1). 107 - 109. ISSN 0363-8111 DOI: https://doi.org/10.1016/j.pubrev.2013.10.010

Link to Leeds Beckett Repository record:

https://eprints.leedsbeckett.ac.uk/id/eprint/3/

Document Version:

Article (Accepted Version)

The aim of the Leeds Beckett Repository is to provide open access to our research, as required by funder policies and permitted by publishers and copyright law.

The Leeds Beckett repository holds a wide range of publications, each of which has been checked for copyright and the relevant embargo period has been applied by the Research Services team.

We operate on a standard take-down policy. If you are the author or publisher of an output and you would like it removed from the repository, please contact us and we will investigate on a case-by-case basis.

Each thesis in the repository has been cleared where necessary by the author for third party copyright. If you would like a thesis to be removed from the repository or believe there is an issue with copyright, please contact us on openaccess@leedsbeckett.ac.uk and we will investigate on a case-by-case basis. 


\title{
Crisis? What Crisis?
}

\section{How European communication professionals handle crises and crisis communication}

\begin{abstract}
A broad study in 43 European countries shows that $70 \%$ of communication professionals encounter at least one crisis a year, mostly institutional, related to the performance of the organization or a crisis in management or leadership. Response and image restoration approaches are mainly based on information, sympathy and defense strategies. Traditional media relations and personal communication are the most important instruments used in crisis communication, while social media is used less often. The variation of crisis types, responses and instruments across European regions and types of organization indicate that economic and cultural aspects play a role in defining a crisis and communicating about it.
\end{abstract}

Key words: crisis communication, media, European Communication Monitor 2013

\section{Introduction}

An organizational crisis can be defined as "the perception of an unpredictable event that threatens important expectancies of stakeholders and can seriously impact an organisation's performance and generate negative outcomes" (Coombs, 2012: 2). Crisis communication research shows that organizations use different strategies in response to a crisis (Coombs, 2012) amongst others to restore their image (Benoit, 1997). The traditional gatekeeping media, although understudied in organizational crisis communication, seem to have the ability to prevent crisis escalation due to their 
damping effect on social media messages about a crisis (Van der Meer \& Verhoeven, 2013). The question is how communication professionals in organizations handle crises and crisis communication. In this research we therefore raise the following research questions:

RQ1: How relevant are crisis situations in communication management?

RQ2: Which kind of crisis situations are most important for organizations and communication management?

RQ3: Which crisis communication strategies and instruments are most often used for crisis situations?

\section{Methodology}

For this research, three questions about crises and communication have been included in the European Communication Monitor (ECM) 2013 (Zerfass et al., 2013). The ECM is an annual survey among European communication professionals conducted since 2007 by a research group from five European universities led by the University of Leipzig in Germany.

Before the English language survey was launched in March 2013, a pre-test with 36 practitioners in 13 European countries was held. The questions about crisis were part of the larger survey that in total consisted of a questionnaire with 18 sections and 39 questions. 30,000+ Professionals throughout Europe were invited to join the survey. They received a personal invitation via e-mail based on the database provided by the EACD. Additional invitations were sent via national branch associations and networks. 4,808 respondents started to fill out the survey and 2,802 of them completed it. Participants that were clearly identified as not being part of the 
population of communication professionals were removed from the dataset, leaving 2,710 fully completed surveys from 43 European countries.

$43.2 \%$ of the respondents are communication manager or CEO of a communication consultancy, $28.4 \%$ are responsible for a single communication discipline or are leaders of a department and $22.5 \%$ are member of a communication professionals team of or a consultants. The majority of the respondents have more than ten years of experience (58.3\%), are female (58\%) and are on average 40.9 years old. $67.1 \%$ of the respondents have a Master's degree or higher. The vast majority of $74.8 \%$ work in communication departments in organisations (joint stock company, $26.2 \%$, private company, $18.9 \%$; government-owned, public sector, political organisation, $16.3 \%$ and non-profit organisation, association, 13.45), and 25.2 per cent of the respondents are communication consultants working freelance or for agencies and consultancies. Most respondents (35.3\%) work in Western Europe, followed by Northern Europe (26.2\%), Southern Europe (24.5\%) and Eastern Europe (14.1\%).

\section{Findings}

$70.4 \%$ of the respondents $(N=2687)$ encountered one or more crises in the past year; almost half of them $(49.8 \%, N=1337)$ several times. Professionals in Southern and Eastern Europe encountered a crisis more often than professionals in Western and Northern Europe, respectively $77 \%$ and $75.5 \%$ versus $64.5 \%$ and $69.4 \%$. These differences are significant $\left(\chi^{2}=40.785, \mathrm{p}<.001\right)$ but the correlation is weak (Cramer's $V=.09, \mathrm{p}<.001)$. Communication consultants are most confronted with crises, $77.1 \%$, followed by professionals in joint stock companies, $74.4 \%$, government organizations, $69.5 \%$, private companies, $65.4 \%$ and non-profit organizations, $57.7 \%$ $\left(\chi^{2}=65.694, \mathrm{p}<.001\right.$, Cramer's $\left.V=.11, \mathrm{p}<.001\right)$. Asked about the most important 
crises of the last year respondents $(N=1899)$ mention institutional crises (e.g. adverse campaigns by critics, a threat of political regulation, a hostile takeover attempt) and performance crises (e.g. product or service failure, breakdown of production lines) most often, $13.7 \%$, followed by a management or leadership crisis (e.g. top management succession, compliance problem, ethical misbehavior), 12.1\%, financial or economic crisis (e.g. declining revenue and profit, loss of market share), 9.7\%, a crisis based on rumors or communication failure, $5.9 \%$, an industrial relations crisis (e.g. conflict with workers or unions, strikes), 5.4\% and a natural crisis (e.g. disaster, accident), 4.3\%. These types of crises differ significantly per European region $\left(\chi^{2}=72.142, \mathrm{p}<.001\right)$ counting more financial or economic crises in Southern and Eastern Europe and more management and leadership crises in Western and Northern Europe. The correlation between type of crisis and region is weak, but significant (Cramer's $V=.11, \mathrm{p}<.001)$. The crises differ also significantly across types of organizations $\left(\chi^{2}=98.174 .142, \mathrm{p}<.001\right)$ with for example most financial problems in private companies and most management and leadership crises in nonprofit organizations. The correlation between type of crises and organization is weak (Cramer's $V=.11, \mathrm{p}<.001)$.

Asked which kind of communication strategies professionals use in the most important crisis the data show that the information strategy is by far the most used strategy, $82.9 \%(N=1890)$. Informing, providing stakeholders with facts and figures about the situation, explaining next steps etc. is at a great distance followed by the sympathy strategy characterized by expressing sympathy with those who were harmed by the crisis and underlining the competencies and serious intentions of the organization, $26.3 \%$ uses that strategy. Third ranks the defense strategy, pointing out that the situation is different, giving alternative interpretations, blaming others, $19.4 \%$, 
fourth the apology strategy, apologizing to stakeholders about the situation, taking responsibility, promising to do better next time and fifth the so-called sit-out strategy characterized by not communicating at all with $16.8 \%$ and $10.2 \%$ respectively. The information strategy is used significantly less in Southern Europe, 78.9\%, than in the other three regions $\left(\chi^{2}=8,36, \mathrm{p}<.05\right.$; Cramers $\left.V=.06, \mathrm{p}<.05\right)$. The sympathy strategy that ranks second in the overall ranking is used significantly less in Southern Europe, $20.9 \%$, as well $\left(\chi^{2}=12,120, \mathrm{p}<.01\right.$; Cramers $\left.V=.08, \mathrm{p}<.01\right)$, making it less used there than the defense strategy. In Southern Europe (22.1\%) the defense strategy is the second most used strategy. This defense strategy is more often used in Southern and Eastern Europe, 23.7\%, than in Western, 16.7\%, and Northern Europe $17.4 \%\left(\chi^{2}=9,801, \mathrm{p}<.05 ;\right.$ Cramers $\left.V=.07, \mathrm{p}<.05\right)$. The apology strategy is more often used in Northern Europe, 21,5\%, compared to the other three regions $\left(\chi^{2}=\right.$ $11,634, \mathrm{p}<.01 ;$ Cramers $V=.08, \mathrm{p}<.01)$. The use of the sit-out strategy does not differ across Europe. Only the use of the defense strategy varies significantly across types of organizations; this strategy is less used by nonprofit organizations than the other types $\left(\chi^{2}=10,615, \mathrm{p}<.05 ;\right.$ Cramers $\left.V=.08, \mathrm{p}<.05\right)$.

Most used communication instruments are media relations (e.g. press information, interviews) by $75.8 \%$ of the respondents. The second instrument is personal communication with key decision makers, $70.8 \%$, followed by owned media of the organization, e.g. websites and internet, $45.2 \%$, social media, $39.9 \%$, dialogue settings, for example roundtables with stakeholders, $35.2 \%$, and paid media, $7.8 \%$. The use of owned media and personal communication varies significantly across Europe, more frequently used in Western and Northern Europe than in Southern and Eastern Europe (owned media: $\chi^{2}=32,115, \mathrm{p}<.001$; Cramers $V=.13, \mathrm{p}<.001$; personal communication $\chi^{2}=43,171, \mathrm{p}<.001$; Cramers $\left.V=.15, \mathrm{p}<.001\right)$. The use of 
instruments in crisis communication varies across type of organization, except for dialogue settings. The correlation between type of organization and all other instruments is weak but significant.

\section{Conclusion}

The survey shows that European communication professionals rather often encounter an "unpredictable event" (Coombs, 2012) in their organization that potentially generates negative outcomes for stakeholders and the performance of the organization. Even so much that crisis and crisis communication surely can be labeled as very relevant and that research in that area is of great importance for the practice.

There are many crisis situations all over Europe and they are differentiated in character by region and type of organization, indicating that the economic and cultural context of organizations plays an important role in the genesis and the labeling of a situation as a crisis. Key aspects in crisis response and image restoration strategies are information, sympathy and defense. These three approaches are used all over Europe with sympathy and defense trading places in Southern and Eastern Europe versus Western and Northern Europe, again possibly related to the economic and cultural context. Concerning communication instruments used in crises the traditional media relations are most important which is in line with evidence that the traditional media have a damping effect on crisis communication of the public (Van der Meer \& Verhoeven, 2013). Media relations are closely followed by personal communication with stakeholders showing that personal contacts and open communication channels in a network are important for a crisis situation. The variation of instruments used by different types of organizations, except for dialogue, is an indication that crisis communication might be more dependent on the organizational context and culture 
and less on professional considerations backed by empirical evidence. This is an interesting issue for further research in crisis and crisis communication.

\section{References}

Benoit, W. (1997). Image repair discourse and crisis communication. Public Relations Review, 23(2), 177-186.

Coombs, W. T. (2012). Ongoing crisis communication: Planning, managing, and responding, 3rd ed. Los Angeles, CA: Sage.

Van der Meer, T. G. L. A., \& Verhoeven, P. (2013). Public framing organizational crisis situations: Social media versus news media. Public Relations Review, 29, 299231.

Zerfass, A., Moreno, A., Tench, R., Verčič, D., \& Verhoeven, P. (2013). European Communication Monitor 2013. A Changing Landscape - Managing Crises, Digital Communication and CEO Positioning in Europe. Results of a Survey in 43 Countries. Brussels: EACD/EUPRERA, Helios Media. 